\title{
Combustion Characteristics of Flat Panel Televisions With and Without Fire Retardants in the Casing
}

\author{
Matthew Blais*, Fire Technology Department, Southwest Research Institute, \\ 6220 Culebra Rd, San Antonio, TX 78238, USA \\ Karen Carpenter, Fire Technology Department, Southwest Research Institute, \\ San Antonio, TX, USA
}

Received: 11 February 2014/Accepted: 16 June 2014

\begin{abstract}
A series of flat panel television burns were performed with incrementally increasing ignition sources in a single burning item apparatus. A comparison study was performed of like model televisions for the United States, Mexican and Brazilian markets. Heat release rate, smoke, combustion gas, TO-15 vapor, and halo-dioxin and furan generation were measured. A total of 18 televisions were ignited and their burning behavior studied to examine the impact of materials of construction and the presence of fire retardants in the casing of the televisions on fire growth. US market televisions required more than $500 \mathrm{~W}$ with greater than $180 \mathrm{~s}$ exposure to ignite and in four out of the 6 trials these televisions did not achieve sustained ignition. In the two cases where sustained ignition for the US market televisions occurred, it was not the flat panel display television itself which ignited, but the stand and mounting bracket which lead to fire growth. Mexican and Brazilian market televisions ignited easily with $60 \mathrm{~s}$ exposure to a $50 \mathrm{~W}$ flame. US market televisions did produce brominated dioxins or furans but the mass loss of these televisions was much lower.
\end{abstract}

Keywords: Flat panel televisions, SBI testing, Smoke toxicity, Calorimetry, pHHR, Dioxins and furans

\section{Introduction}

Modern televisions have changed dramatically in design and materials of construction from those of just 15 years ago. Flat panel designs now dominate the marketplace. Large screen flat panel display televisions, $\geq 30$ inches, represent the vast majority of televisions sold internationally. Previous studies on televisions studied consol type and or cathode ray tube (CRT) systems with smaller screens and different materials of construction [1-3]. However data on modern FPD televisions combustion as described here has not been previously published in peer reviewed journals. Because polymeric materials are used in modern FPD televisions, these devices can contribute to fires as either the first item ignited, either by internal or external sources, or by becoming a second item ignited and adding to the overall fuel load. International markets also have different requirements for

\footnotetext{
* Correspondence should be addressed to: Matthew Blais, E-mail: mblais@swri.org
} 
resistance to fire with the United States having the strictest standards for ignitability [4]. The statistical analysis of Hall points to the V rating from UL94 standard fire testing for the television housing as a driver for the better performance of televisions in the US market as compared to their European counterparts [5]. For these reasons a study was performed using small flame, external ignition sources applied to televisions that were procured during 2013 in Brazil, Mexico and the United States. Matching sizes and models were used to do a comparison of the response to ignition. Flame spread, heat of combustion, smoke production and toxic constituents of smoke were all measured in this study [6].

Underwriters Laboratories, UL, has released a comparative video [7] that shows fire loading from furnishings in modern household living rooms has increased dramatically compared to legacy rooms from the 1970s. Kerber's study also does an excellent job of describing the impact of fuel growth of modern materials in residential fire [8]. The high energy content of modern rooms can lead to flashover conditions in as little as three to $4 \mathrm{~min}$ as compared to $29 \mathrm{~min}$ to $30 \mathrm{~min}$ in the legacy room. The use of polymeric materials in our homes is a significant contributor to this increased fire load. Most polymers decompose to low molecular weight vaporous components during pyrolysis [9] which burn with a large amount of energy release leading to rapid fire growth. For this reason, many modern polymers incorporate fire retardants (FR) that inhibit ignition while not significantly altering the mechanical and physical properties of the material [10-12].

Incorporation of $\mathrm{FR}$ in the cabinets of televisions has sparked controversy because of claims of potential health hazards. The proponents of the health hazard claims are pushing for the removal of the external ignition testing requirements for materials used in the construction of these televisions [13, 14]. Further, these groups are pushing manufacturers to cease the use of plastics with FR and to design the televisions so that potential ignition sources within the television are contained with inherently fire safe construction. The wisdom of eliminating ignition resistant plastics is questionable given media reports and product recalls related to incidences of plasma and LCD television fires that have breached the casing of the television and caused loss of life and many thousands of dollars in damages to homes [15-19].

Fire protection works best when approached from a layered perspective. Use of sprinklers, smoke detectors and inherently fire safe furnishings all increase the probability of preventing or surviving fires and minimizing property damage [20]. Human behavior is the one variable that is hardest to control. Numerous fires have started by placing ignition sources such as candles or heaters next to readily ignitable items made of plastics. Among the reasons that some claim that external flame source testing is not required is based on the assumption that all flat panel television are hung on walls and there is not an opportunity to come in contact with external small ignition sources. This ignores the fact that many of these televisions are mounted on stands sitting on entertainment centers, credenzas, tables and even carpeted floors. This is especially prevalent in apartment complexes where modification of the walls may not be permitted and hotels.

In this study, 18 televisions of three different models of similar sizes and weights were ignited using progressively larger open flame ignition sources of $50 \mathrm{~W}$ and 


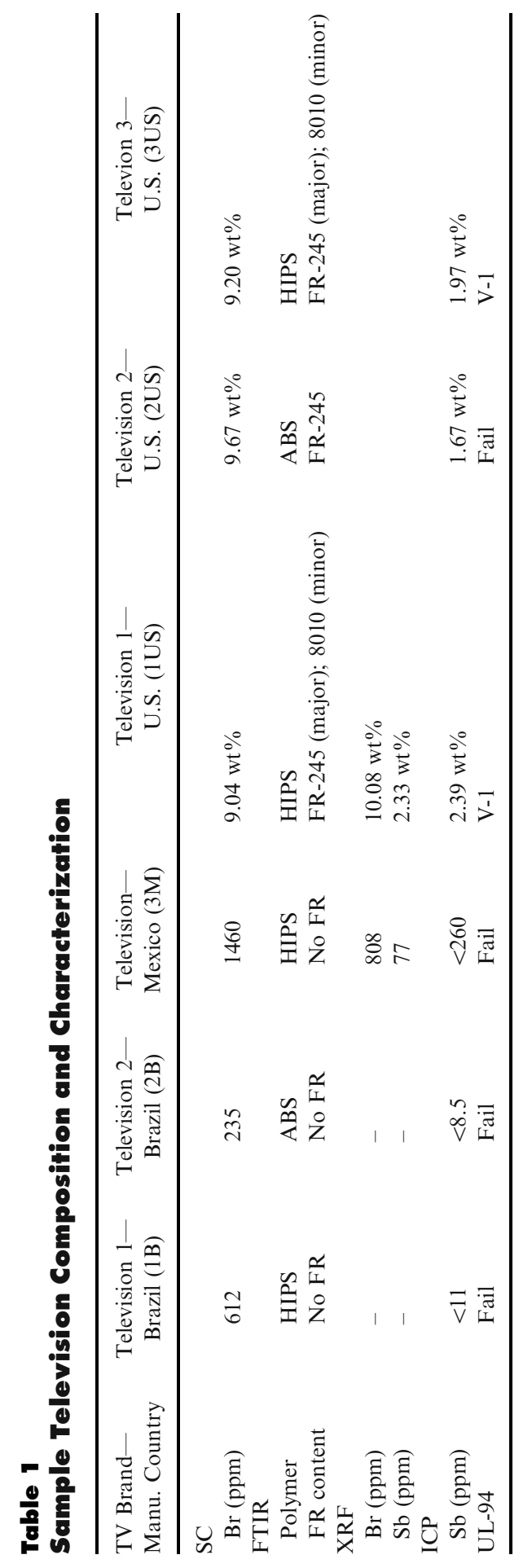


$500 \mathrm{~W}$. Half of the televisions studied were manufactured for the US market and the remaining for the Brazilian and Mexican markets. Televisions were ignited in a single burning item (SBI) apparatus as described in EN 13823: 2010 appendix E and the heat release rate and smoke generation were measured. Mass loss as a result of combustion, combustion gas generation, in-door air pollutant and chlorinated - and brominated - dioxins and furans were also measured.

\section{Experimental}

\subsection{Materials}

The composition and performance of the test items used in this study are summarized in Table 1. The polymer composition of the back case remained the same for the same model of televisions from the different markets excluding FR addition. Analysis of components was performed by Schoeniger Combustion (SC), Fourier

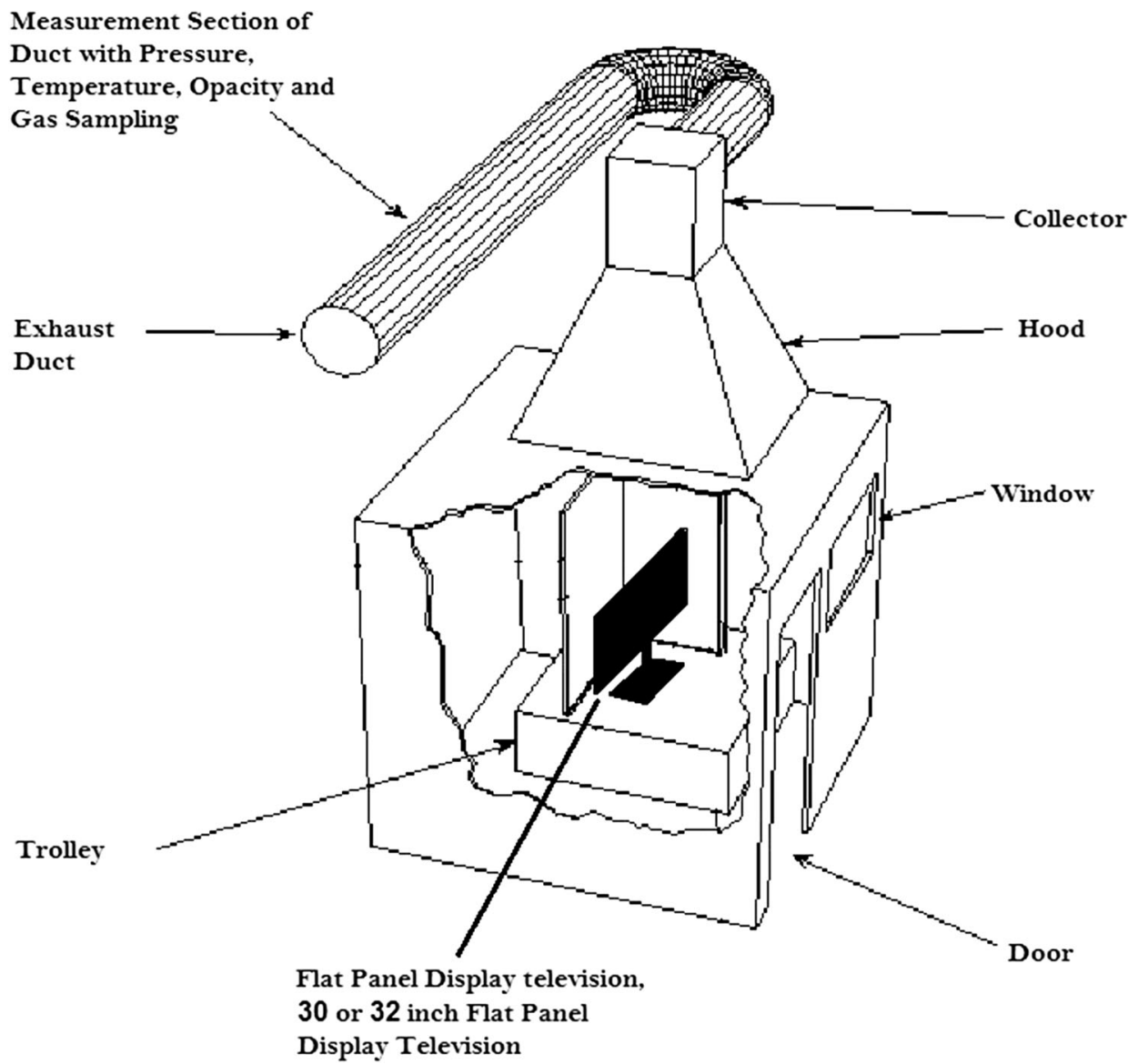

Figure 1. SBI test apparafus schematic. 
Transform Infra-Red spectroscopy (FTIR), X-ray Fluorescence (XRF) and Inductively Coupled Plasma (ICP). Sections of the back casing were tested in accordance with UL-94 and the results are also reported in the table. FR-245 is tris(tribromophenoxy) triazine and FR8010 is Ethane-1,2-bis(pentabromophenyl). Analysis was performed by Mr. Brett Wallet of Albemarle, Baton Rouge, LA.

All televisions were mounted on the manufacturer supplied stands. Items $2 \mathrm{~B}$ and 2US had identical bases with methyl methacrylate (MMA) and acrylonitrilebutadiene-styrene (ABS) with halogen free phosphate and aromatic brominated compounds added but were not fire test rated. The bases for 3M and 3US televisions were composed of MMA ABS containing halogen free phosphate and aromatic brominated compounds but were not fire test rated. The stand for 1US had a UL 94 V0 rated high impact polystyrene (HIPS) cover while the 1B stand cover did not have a fire rating but was also composed of HIPS.

\subsection{SBI Apparatus Tests}

A standard SBI test apparatus as described in EN 13823 appendix E was used for all television burns. Figure 1 shows a schematic drawing of the SBI test apparatus as used with the location of the television indicated in the drawing. Smoke density was measured via opacity in the exhaust duct. Heat release was measured as a function of oxygen consumption and carbon monoxide and carbon dioxide production. The sampling rate for the data acquisition system was $1 \mathrm{~Hz}$.

\subsection{Gas Sampling and Analysis System}

An isokinetic sampling probe was positioned centroid to the SBI exhaust duct. A heated sample transfer line was attached to the duct probe. An EPA Method 23A sample train was attached to the heated line and the system was used to analyze for chlorinated and brominated dioxins and furans. Dioxin and furan analysis was performed by high resolution gas chromatography and high resolution mass spectrometry based on EPA Method 8290. A Summa Canister ${ }^{\mathrm{TM}}$ was also attached to sample for EPA method TO-15 to measure 98 standard volatile organic indoor pollutants as well as tentatively identified compounds via mass spectroscopy. The sample line was also attached to a Thermo Fischer Nicolet 6700 FTIR equipped with a 2-m gas cell, potassium bromide windows and gold reflectors to perform analysis of combustion gases in based on a partial least squares calibration of nine combustion gasses with a detection limit of $5 \mathrm{ppm}$ or less. Sample gases were drawn through the gas cell at constant pressure of $756 \mathrm{~mm} \mathrm{Hg}$ and a flow of approximately 1.5 SLPM which resulted in a concentration rise time of less than $30 \mathrm{~s}$ as verified during calibration.

Plastic composition and FR content determination was performed by an external laboratory and is reported in the sample description of the materials section.

\section{Procedures}

One of each type of television mounted on the manufacturers supplied stand was put through progressively increasing ignition source intensity and duration. The 


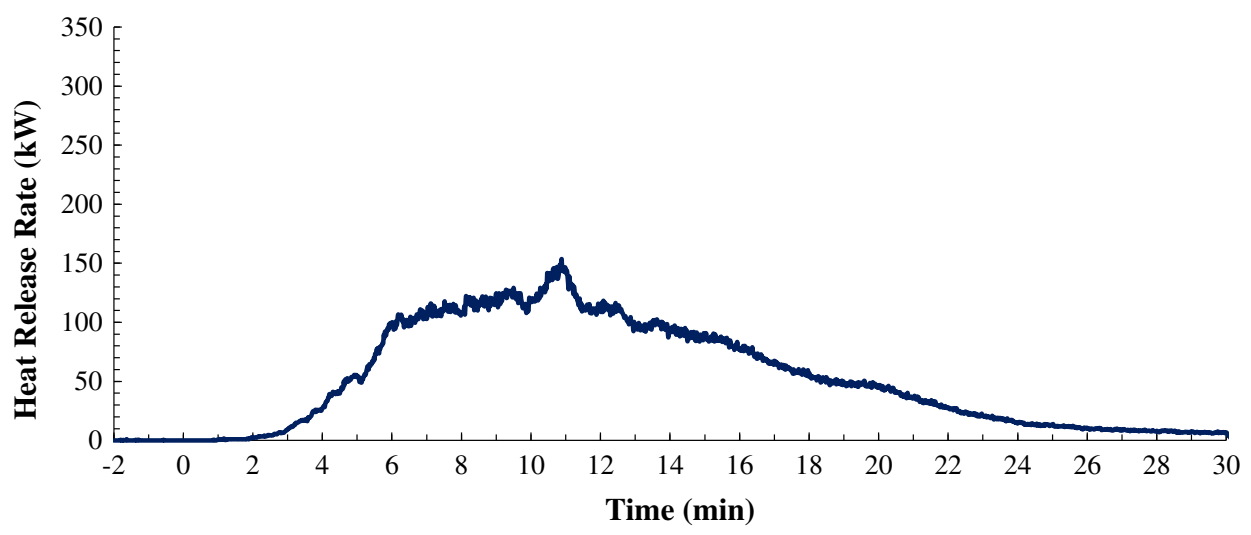

Figure 2. Heat release for Tesł 1 Television 1 B.

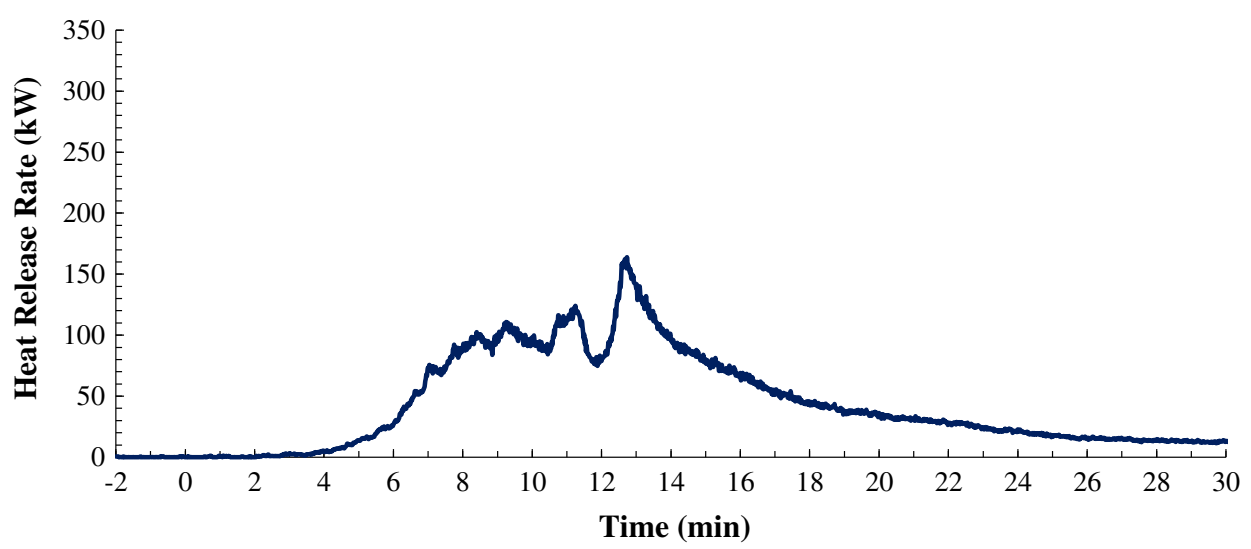

Figure 3. Heat release for Test \#2, Mexican Market M3.

ignition source was applied to the back, bottom edge of each television. A summary of the individual tests is presented in the results section. The initial ignition source was a $12 \mathrm{~mm}$ needle flame which is equivalent to a small candle flame as described in IEC 60695-11-5. Exposure times of $60 \mathrm{~s}$ and $180 \mathrm{~s}$ were used to try and achieve sustained ignition. The next progressive ignition source was a $50 \mathrm{~W}$, $20 \mathrm{~mm}$ flame as described in UL 94 section 8 applied twice for $10 \mathrm{~s}$ intervals, then $60 \mathrm{~s}$, and $180 \mathrm{~s}$, The largest ignition source applied was a $500 \mathrm{~W}, 125 \mathrm{~mm}$ flame as described by UL 94 section 9 . Successive exposures of 2 at $10 \mathrm{~s}$, then $60 \mathrm{~s}$ and $180 \mathrm{~s}$ were used until sustained ignition was achieved. The data obtained from the progressive ignition source test determined the ignition sequence for the follow-on tests of the same item type. Subsequent tests used the largest ignition source with the longest duration condition required to ignite the test items of like manufac- 


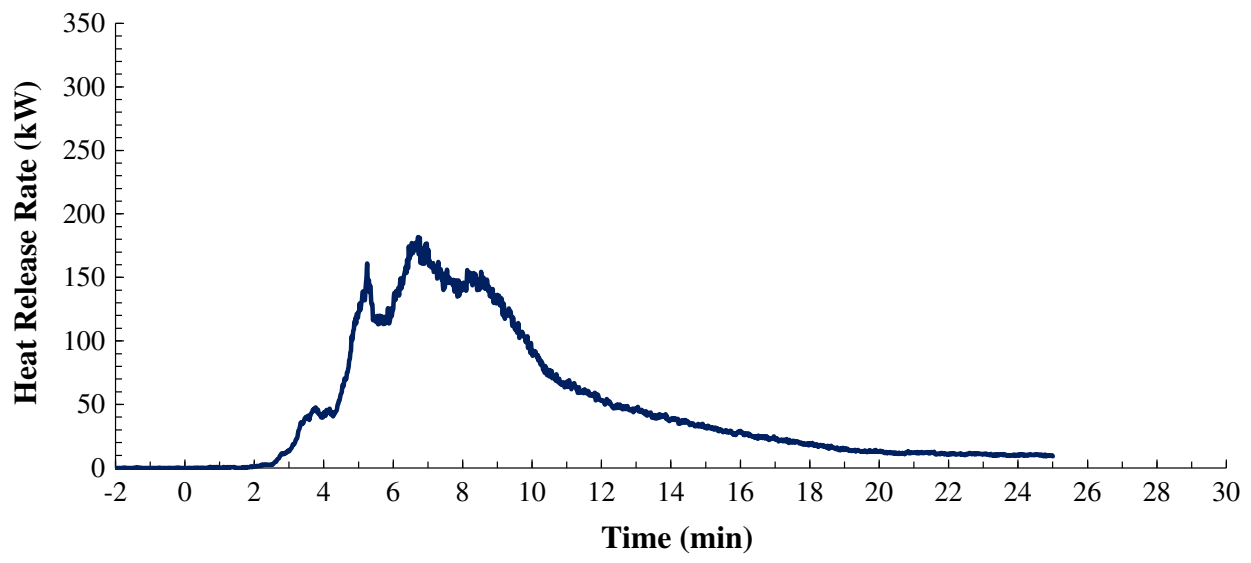

Figure 4. Test \#3 Brazilian Market television 2B, 32 " heat release rate.

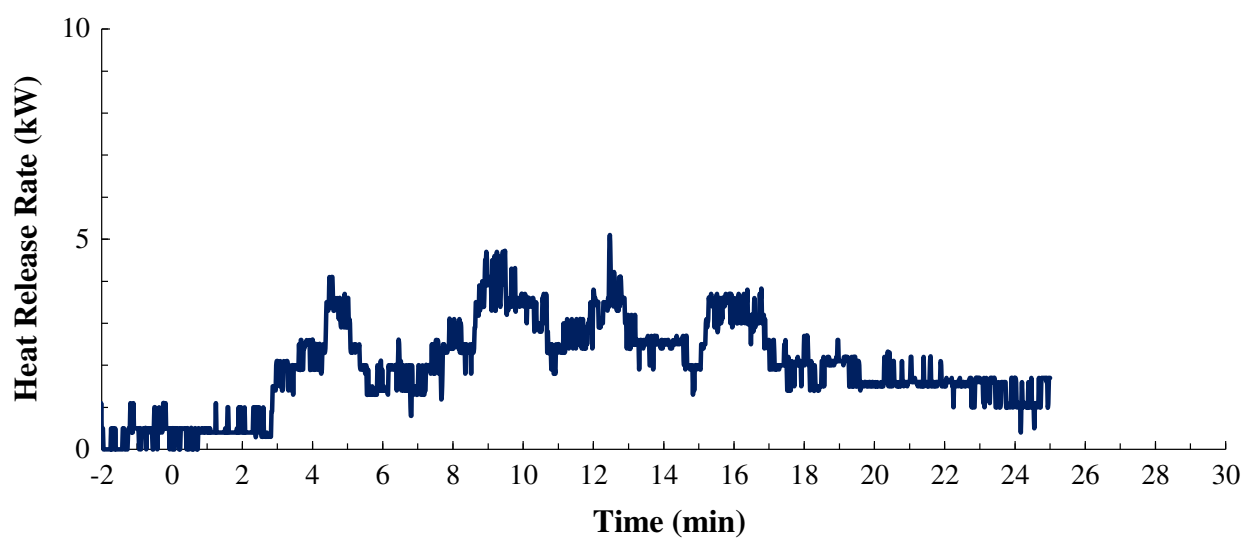

Figure 5. Test \#4, US market television 1 US.

ture. The data was also used to determine the collection time for the Summa canisters. Canisters were collected at $\mathrm{pHR}$ and peak smoke generation times to determine EPA TO-15 indoor air pollutants concentrations. In the second and third tests for each television type, sampling was performed for dioxins and furans over the duration of the entire test.

\section{Results}

In the progressive ignition portion of the testing for test \#1, the Brazilian market television $1 \mathrm{~B}$ ignited with a $60 \mathrm{~s}$ exposure to the needle burner. The fire produced sooty black smoke with the first flaming drops occurring at $24 \mathrm{~s}$. The television 
stand collapsed at $316 \mathrm{~s}$ with a resulting rapid increase in heat release as seen in Figure 2. The flame propagation covered the entire back surface of the television as well as the front screen and the interior components.

In test \#2, the Mexican market television 3M was ignited with a $60 \mathrm{~s}$ exposure to the needle burner. The first burning droplets fell onto the stand with the result of the stand also catching fire at $102 \mathrm{~s}$. The fire produced black sooty smoke with the stand collapsing at $510 \mathrm{~s}$. Figure 3 shows the heat release rate for this test.

In test \#3 a 32 inch Brazilian market television 2B was ignited after exposure to the needle burner for $60 \mathrm{~s}$. The first flaming droplets were noted at $111 \mathrm{~s}$ resulting in the stand catching fire and collapsing at $320 \mathrm{~s}$. Figure 4 shows the heat release rate for test \#3. The rapid increase in energy release corresponds to the base catching fire. The first flaming drips were seen between $5 \mathrm{~min}$ and 6 min with the subsequent rapid increase corresponds to the collapse of the TV stand.

In test \#4 the first of the US market television 1US was subjected to the needle burner for $60 \mathrm{~s}$ with the result of a guttering flame that extinguishes at $87 \mathrm{~s}$. The needle burner was then applied for $180 \mathrm{~s}$ with flames extinguishing at $192 \mathrm{~s}$. A $50 \mathrm{~W}$ flame source was then applied to the television for $2 \mathrm{~s}$ to $10 \mathrm{~s}$ intervals, a $60 \mathrm{~s}$ interval and a $180 \mathrm{~s}$ interval all with no ignition. The $500 \mathrm{~W}$ flame was then applied to a previously burned area for $60 \mathrm{~s}$ without result followed by an additional $180 \mathrm{~s}$ which breached the casing and resulted in a very slow fire with a peak heat release rate of $5 \mathrm{~kW}$ and very little overall mass loss for the television. Figure 5 shows the heat release rate for this test with the $\mathrm{Y}$ axis scale expanded to show more detail.

In test \#5, a US market television 3US was also subjected to the progressive ignition regime with very similar results as obtained in Test \# 4 . The needle burner was applied for $60 \mathrm{~s}$ with the result of a guttering flame that extinguishes at $96 \mathrm{~s}$. Flaming drops were noted at $81 \mathrm{~s}$ that extinguished on impact with the floor. The needle burner was then applied for $180 \mathrm{~s}$ with flames extinguishing upon removal of the burner. The casing material melted during this process and retreated from the flame. A $50 \mathrm{~W}$ flame source was then applied to a different

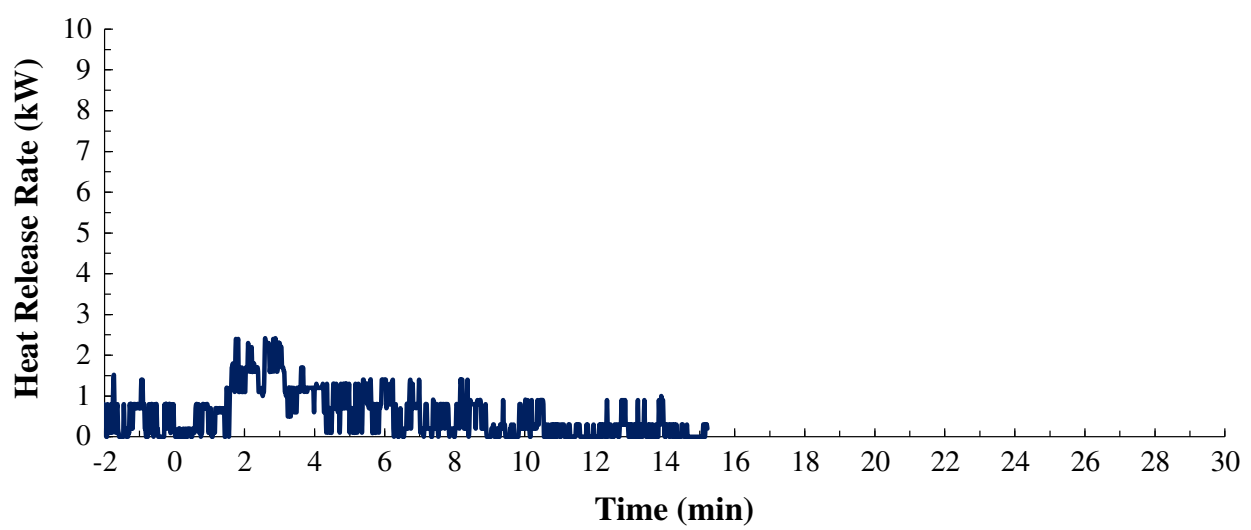

Figure 6. Test \#5 Heat Release rate US Market television 3 US. 


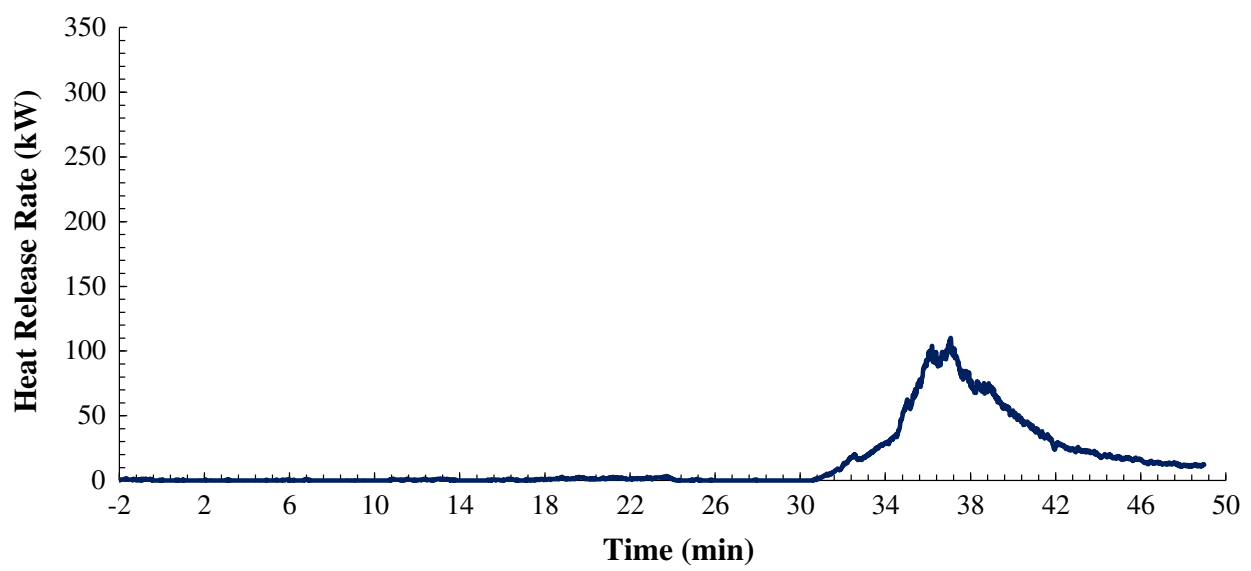

Figure 7. Test \# 1 7, Heat release for US market television 2 US.

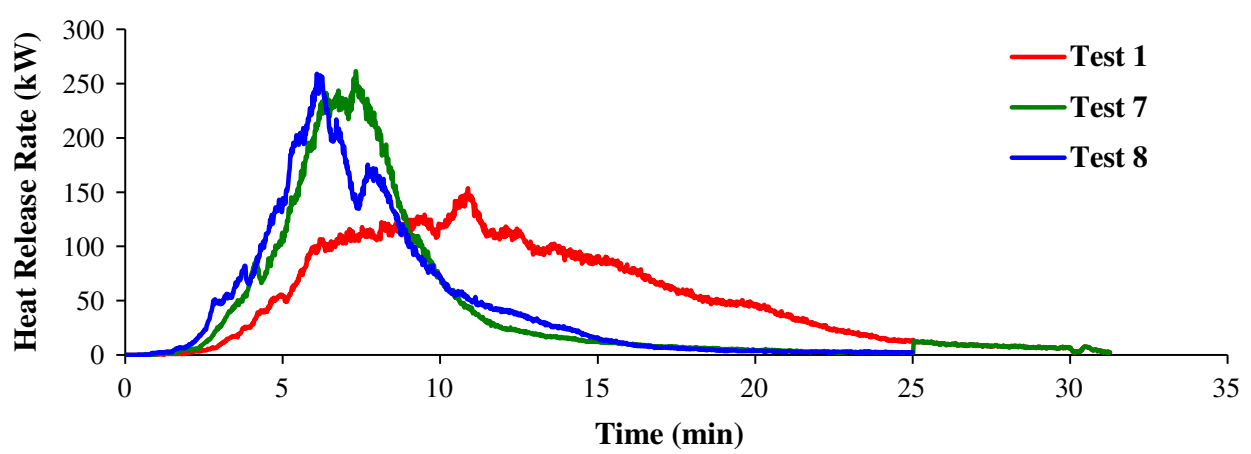

\section{Figure 8. Combined Heat Release Rate Plots for 3 Brazilian Market Model 1 B Televisions.}

area of the television for $2 \mathrm{~s}$ to $10 \mathrm{~s}$ intervals, a $60 \mathrm{~s}$ interval and a $180 \mathrm{~s}$ interval all with no ignition. The $500 \mathrm{~W}$ flame was then applied to a previously burned area for $60 \mathrm{~s}$ without result followed by an additional $180 \mathrm{~s}$ but melting drops extinguished the burner at $105 \mathrm{~s}$. The Burner was relit and the exposure continued for the remaining time. At $150 \mathrm{~s}$ into the exposure flaming drops were produced. A $180 \mathrm{~s}$ exposure was then performed on a previously tested part of the surface which produced a breach in the case and produced a slow fire that produced flaming drops. The fire self extinguished at $14 \min 30 \mathrm{~s}$. A pHRR of $2 \mathrm{~kW}$ was obtained as shown in Figure 6.

The last of the progressive ignition tests was planned to be test \#6 however the ignition source was applied to the stand mounting bracket instead of the television case. The stands were determined to be a different material and were not UL-94 fire test rated. Test \#17 using US market television 2US was the final progressive ignition experiment and was determined to be very similar to test 4 and 5 . The 


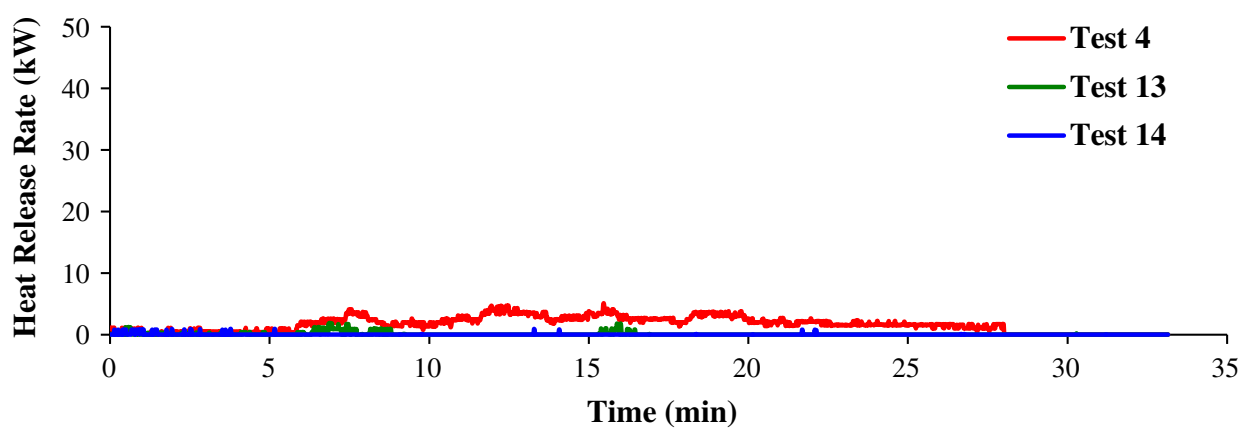

Figure 9. Combined Heat Release Rate Plots for 3 US Market Model 1 US Televisions.

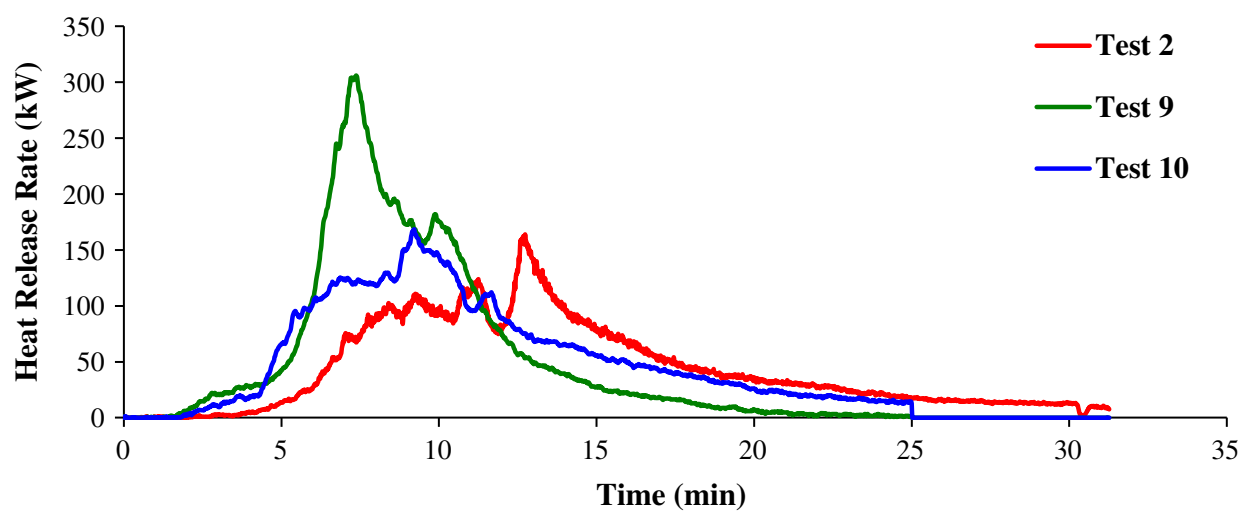

\section{Figure 10. Combined Heat Release Rate Plots for 3 Mexican Market Model 3M Televisions.}

television was subjected to the needle flame for $60 \mathrm{~s}$ with the result of immediately extinguishment on removal of ignition source. The needle flame was then applied for $180 \mathrm{~s}$ with flames extinguishing at $180 \mathrm{~s}$. A $50 \mathrm{~W}$ flame source was then applied to the television for $60 \mathrm{~s}$ with the flame extinguishing in $62 \mathrm{~s}$. It was then was then applied for $180 \mathrm{~s}$ with flames extinguishing at $180 \mathrm{~s}$. The $500 \mathrm{~W}$ flame ignition source was then applied for $10 \mathrm{~s}$ without ignition followed by a $60 \mathrm{~s}$ exposure which breached the casing and resulted in a very slow fire over a period of 46 min with a peak heat release rate of $110 \mathrm{~kW}$. Figure 7 shows the heat release rate for test \#17.

In all subsequent tests, a $500 \mathrm{~W}$ ignition source was applied for $180 \mathrm{~s}$ to the back of each television. A total of two of each type of television was challenged under this technique. In all of the non-US market televisions this resulted in higher peak heat release rates in much shorter times. Comparing the 1B and 1US television, same model, gives the greatest contrast as shown in Figures 8 and 9. The Brazilian version reaches $295 \mathrm{~kW}$ in as little as $365 \mathrm{~s}$ while US versions fails 


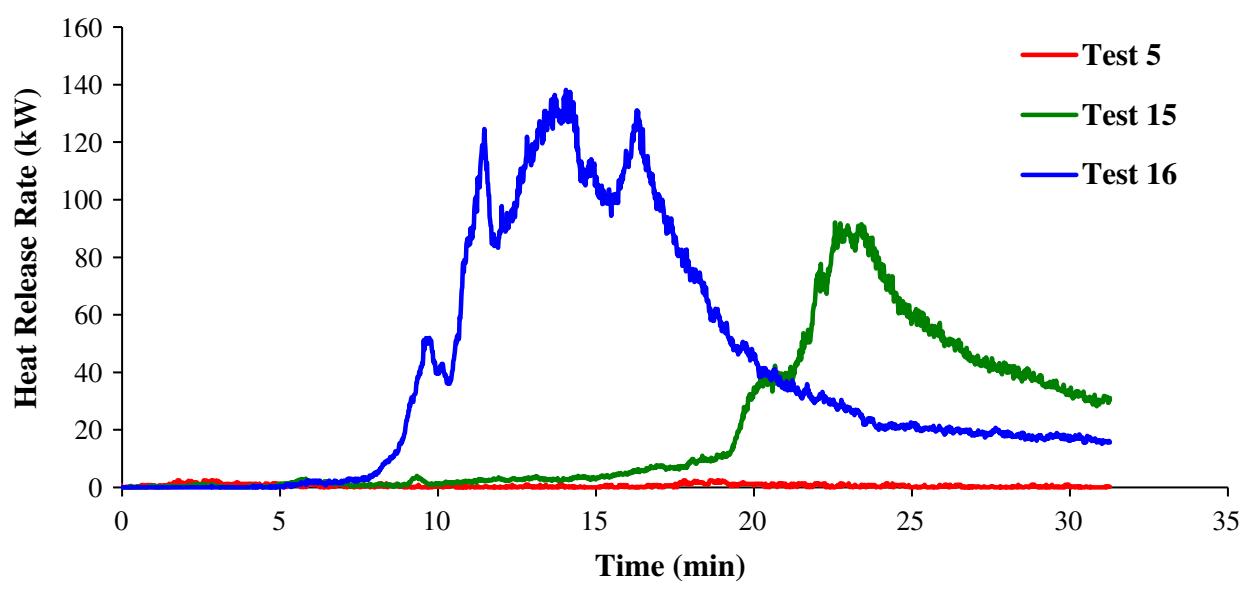

Figure 11. Combined Heat Release Rate Plots for 3 US Market Model 3US Televisions.

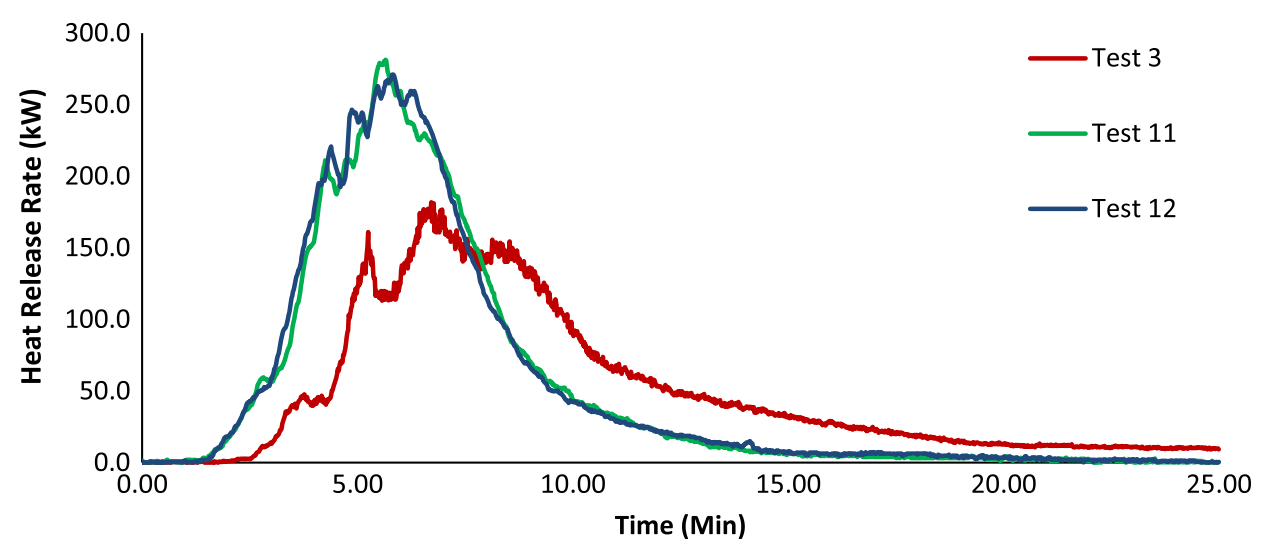

\section{Figure 12. Combined Heat Release Rate Plots for 3 Brazilian Market model 2B televisions.}

to achieve sustained ignition. It is important to note that the red line in Figure 8, test 1 , represents ignition with a needle flame while tests 7 and 8 used the $500 \mathrm{~W}$ burner. The minor differences in the tests 7 and 8 are more a function of the normal variability in flame spread on the surface.

The $3 \mathrm{M}$ and $3 \mathrm{US}$ televisions show the same trend but not as dramatically and there is more variability in the performance for both the US and Mexican market televisions as shown in Figures 10 and 11. This is primarily due to the design and composition of the television stands of this model. None of the stands were rated for fire and were significantly involved in the early stages of the fire in tests 9 ( $2 \mathrm{~min}), 10(2 \mathrm{~min}), 15(3 \mathrm{~min})$ and $16(4 \mathrm{~min})$. The major difference between tests 15 and 16 is that the front face of the television becomes involved in the fire early 


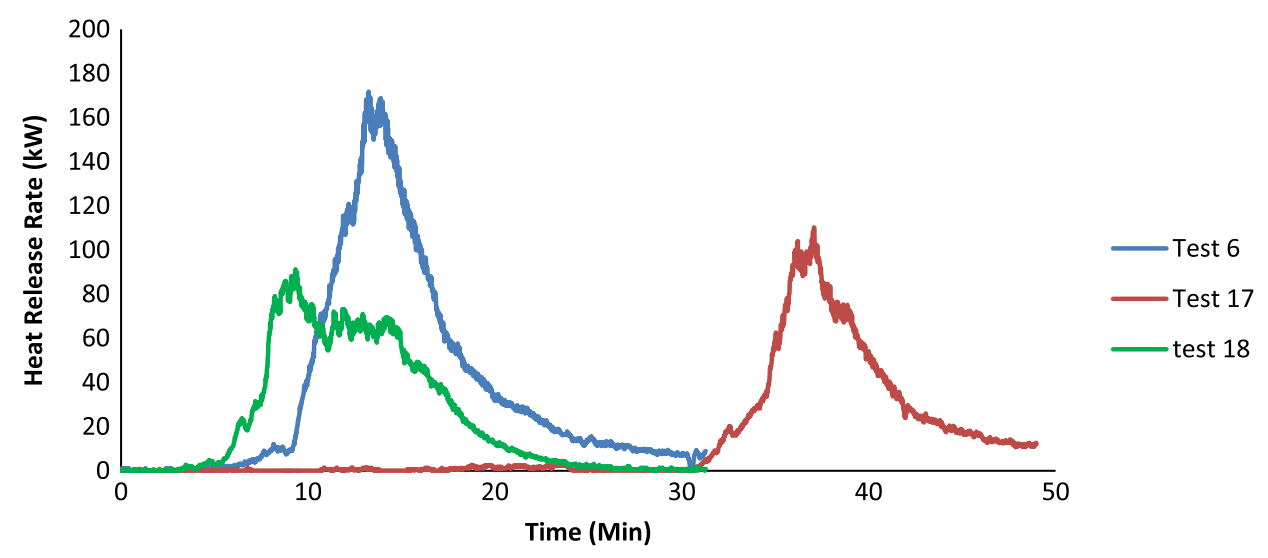

\section{Figure 13. Combined Heat Release Rate for 3 US Market model 2 US} televisions.

in test 16 and not at all in test 15 . In test 5 the stand was not involved in the fire and this television failed to achieve sustained ignition and test number 2 used the smaller, needle flame ignition source.

The 2B and 2US televisions were smaller in size than the other televisions tested in this program being a 32 inch model however the mass of plastics in the rear casing was actually higher than the 40 inch models. All of the tests for the $2 \mathrm{~B}$ and 2US televisions can be found in Figures 12 and 13. The Brazilian televisions burned faster and with greater peak heat release rate than those comparable to the US market using the same ignition source. Test 3 and 6 were ignited with the needle flame. In test 6 , the needle flame came in direct contact with the stand which ignited and resulted in near complete combustion of the television. It did require an extended time to achieve a rapid combustion, approximately $10 \mathrm{~min}$. In the $500 \mathrm{~W}$ ignition source fires the non-FR televisions reached pHRR of near $280 \mathrm{~kW}$ at between 3 and $6 \mathrm{~min}$. In test 17, the stand for the television was not involved in the fire, by selective location of the ignition source, and this television required approximately $30 \mathrm{~min}$ to achieve free burning with a steep rise in heat release rate as shown in Figure 13.

The summary of the heat release and smoke generation data is presented in Table 2. Events with multiple ignition attempts have an asterisk adjacent to pHRR time. Comparing the non-FR television from Brazil and Mexico to the US market televisions shows that the non-FR televisions were easily ignited on their back cases with a small candle flame and that they reach their pHRR in between 6.67 and 13 min. The US market television required much larger ignition sources of longer duration to achieve ignition. Using the larger ignition source on the Brazilian and Mexican television to provide a direct comparison of identical conditions to the US televisions shows that the pHRR for the Brazilian and Mexican televisions nearly doubles and/or the time required to reach $\mathrm{pHRR}$ decreased significantly. For Tests 7 through 16 and test 18, all performed under identical condition, the US market televisions either failed to sustain ignition or burned very 


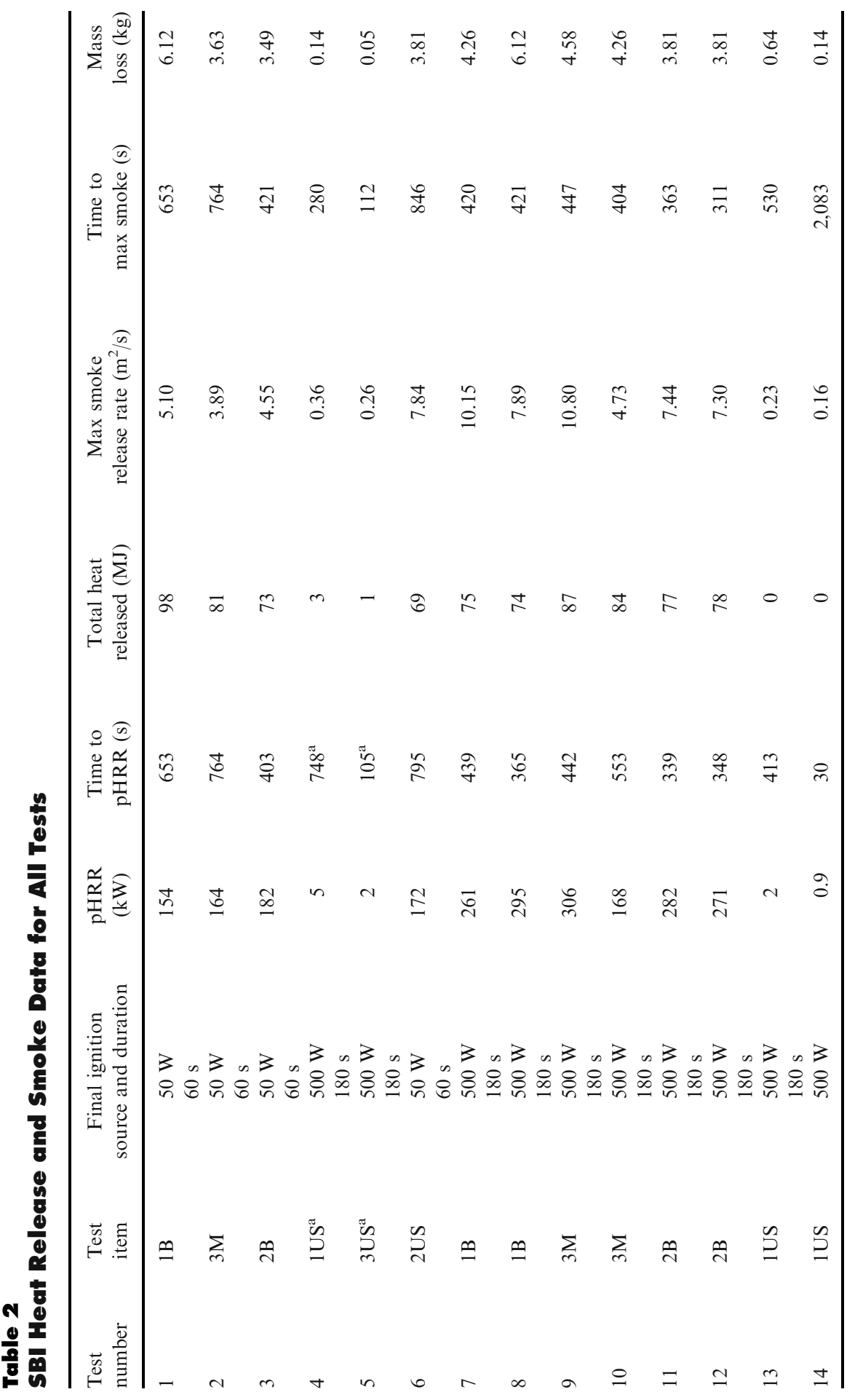




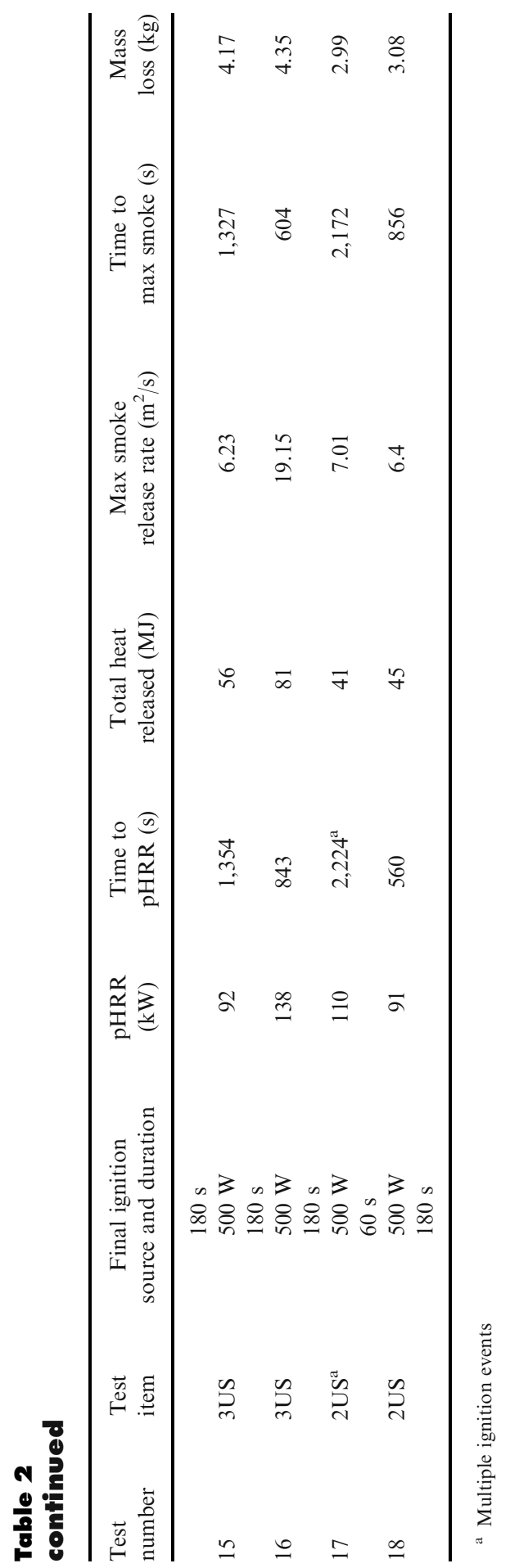




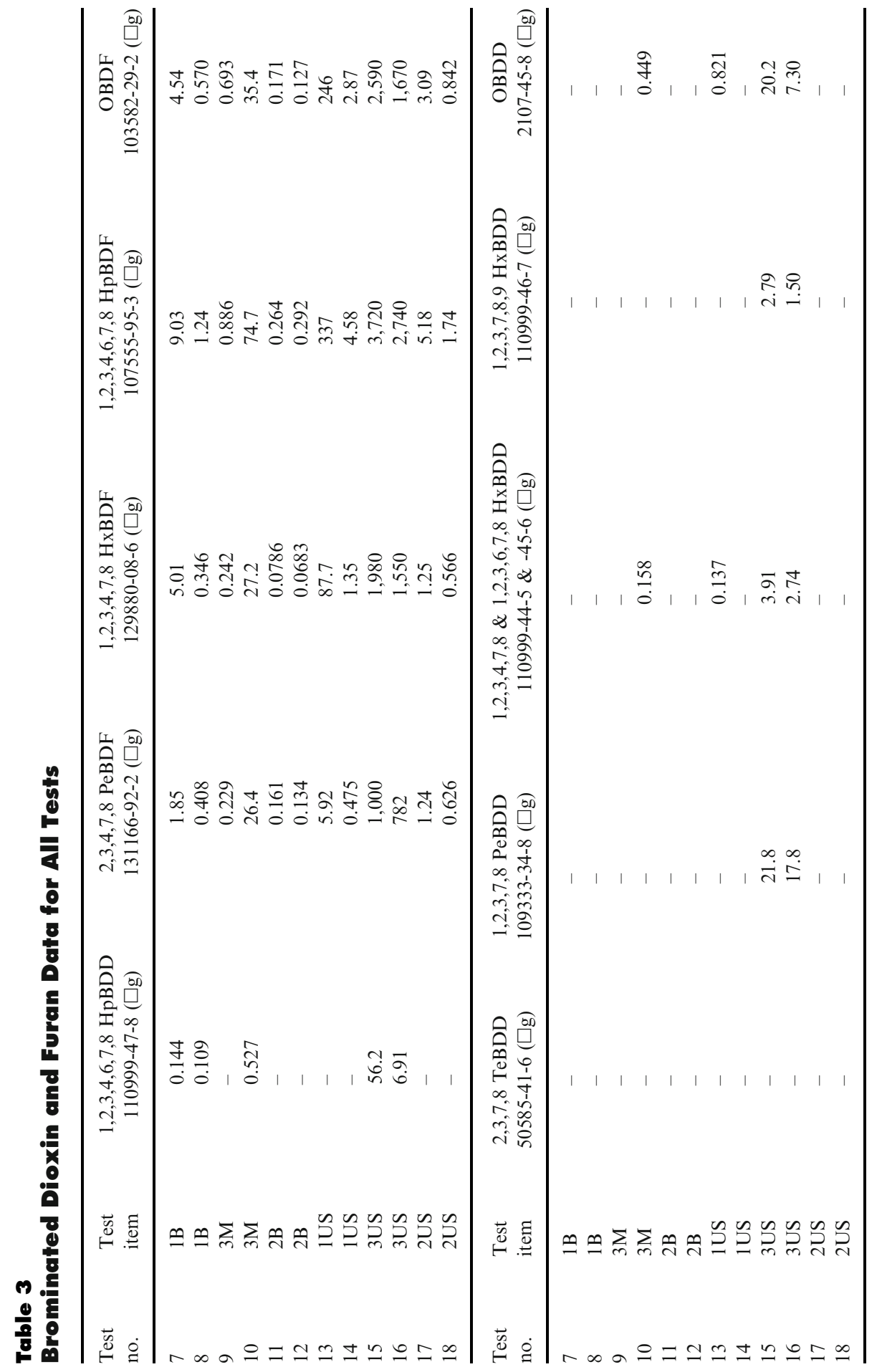




\section{Table 4}

Combustion Gas Analysis for Tests 7-1 8

\begin{tabular}{lcrr}
\hline Test number & Test item & $\mathrm{CO}(\mathrm{ppm})$ & $\mathrm{CO}_{2}(\mathrm{ppm})$ \\
\hline 7 & 1B & 1,100 & 20,000 \\
8 & 1B & 1,690 & 21,900 \\
9 & 3M & 1,730 & 21,800 \\
10 & 3M & 949 & 15,800 \\
11 & 2B & 1,150 & 19,500 \\
12 & 2B & 1,200 & 20,300 \\
13 & 1US & 30 & 108 \\
14 & 1US & 22 & 61 \\
15 & 3US & 292 & 2,980 \\
16 & 3US & 1,490 & 14,500 \\
17 & 2US & 26 & 1,170 \\
18 & 2US & 856 & 8,390 \\
\hline
\end{tabular}

slowly. All of the US market televisions were proven to be compliant with UL 60065 except the 2US televisions which were a marginal fail.

The US market televisions did produce more brominated dioxins and furans than the ones produced for Mexico or Brazil. Table 3 presents the data obtained for tests 7-18 for brominated dibenzo dioxins and furans (BDD and BDF). The total mass of BDD and BDF was calculated by multiplying the found total mass in the collectors by the dilution factor of the duct being sampled. The flow in the duct was $0.60 \mathrm{~m}^{3} / \mathrm{s}$ and the sampler flow was $1.38 \times 10^{-4} \mathrm{~m}^{3} / \mathrm{s}$ giving a dilution factor of 4320 . The numbers obtained for the US Market televisions are rational based on the structures of the FRs normally used in HIPS and ABS plastics [21]. In addition, the samples collected in each trial were also analyzed for chloro dioxins and furans. OCDD, 3268-87-9, was detected at just above background levels in all of the TVs except those made for the Mexican market. Also, 1,2,3,4,6,7,8,HpCDD was detected at near background levels in Test \#8 and \#16.

Combustion gases were also analyzed for the gases listed in ASTM E-800 for tests 7-18. The data indicates that all of the gases of concern were below detection limit except carbon monoxide $(\mathrm{CO})$ and carbon dioxide $\left(\mathrm{CO}_{2}\right)$. The $\mathrm{CO}$ concentration exceeds $1,000 \mathrm{ppm}$ for five out of six of the television for the non-US markets and 2 of those exceed the IDLH value, 1,500 ppm. Only one of the six US televisions exceeded the 1,000 ppm and it did not exceed the IDLH value; the stand was a major contributor to the fire growth in this test. Table 4 presents the data on the peak concentration of the combustion gases for this series of tests.

Each test also had two intervals where Summa ${ }^{\mathrm{TM}}$ canisters were collected to determine other toxic indoor pollutants that were produced during combustion. The first value listed in Table 5 and Table 6 for each test represents the time of the pHRR and the second was collected at peak smoke. For situations where the pHRR and the peak smoke were concurrent, samples were collected in sequence without a time gap.

The TO-15 gases and the TICs shown in Tables 5 and 6 respectively were dependent on the materials of composition of the plastic case and possibly interior 


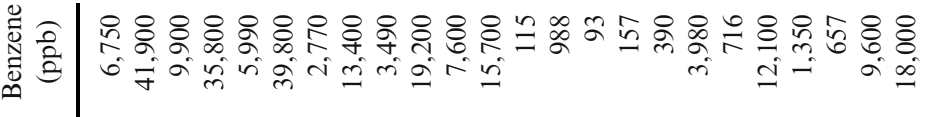

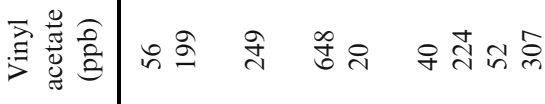

บ

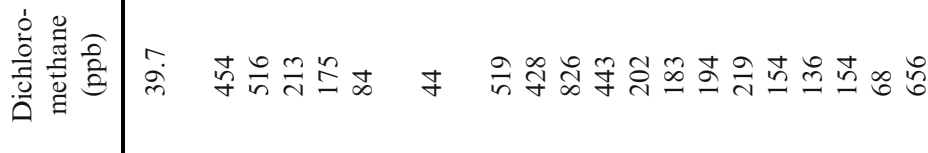

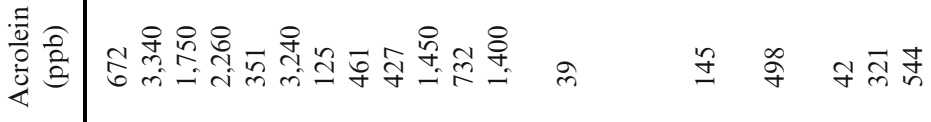

:

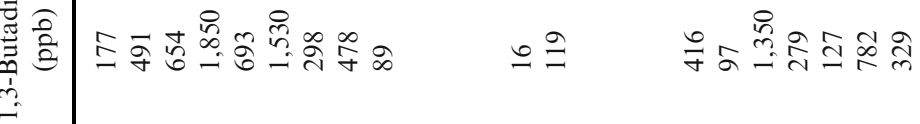

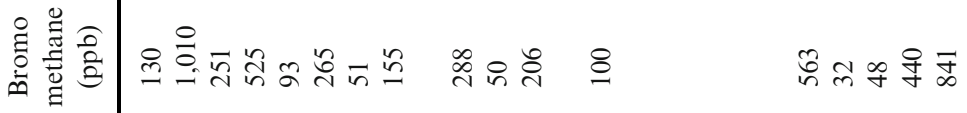

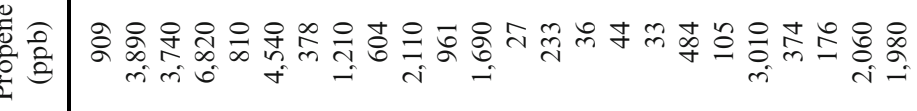




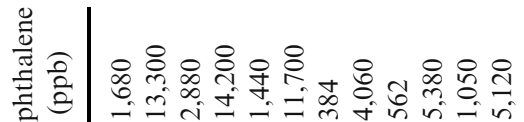

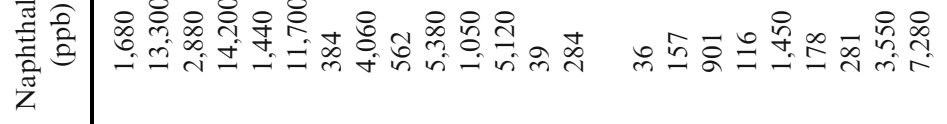

दु

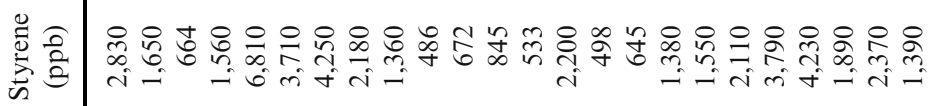

苛

竞

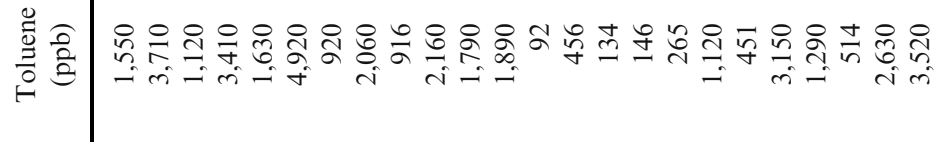

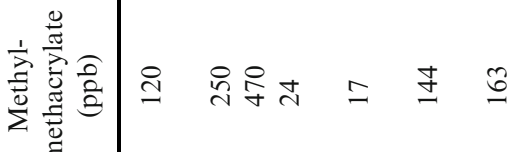




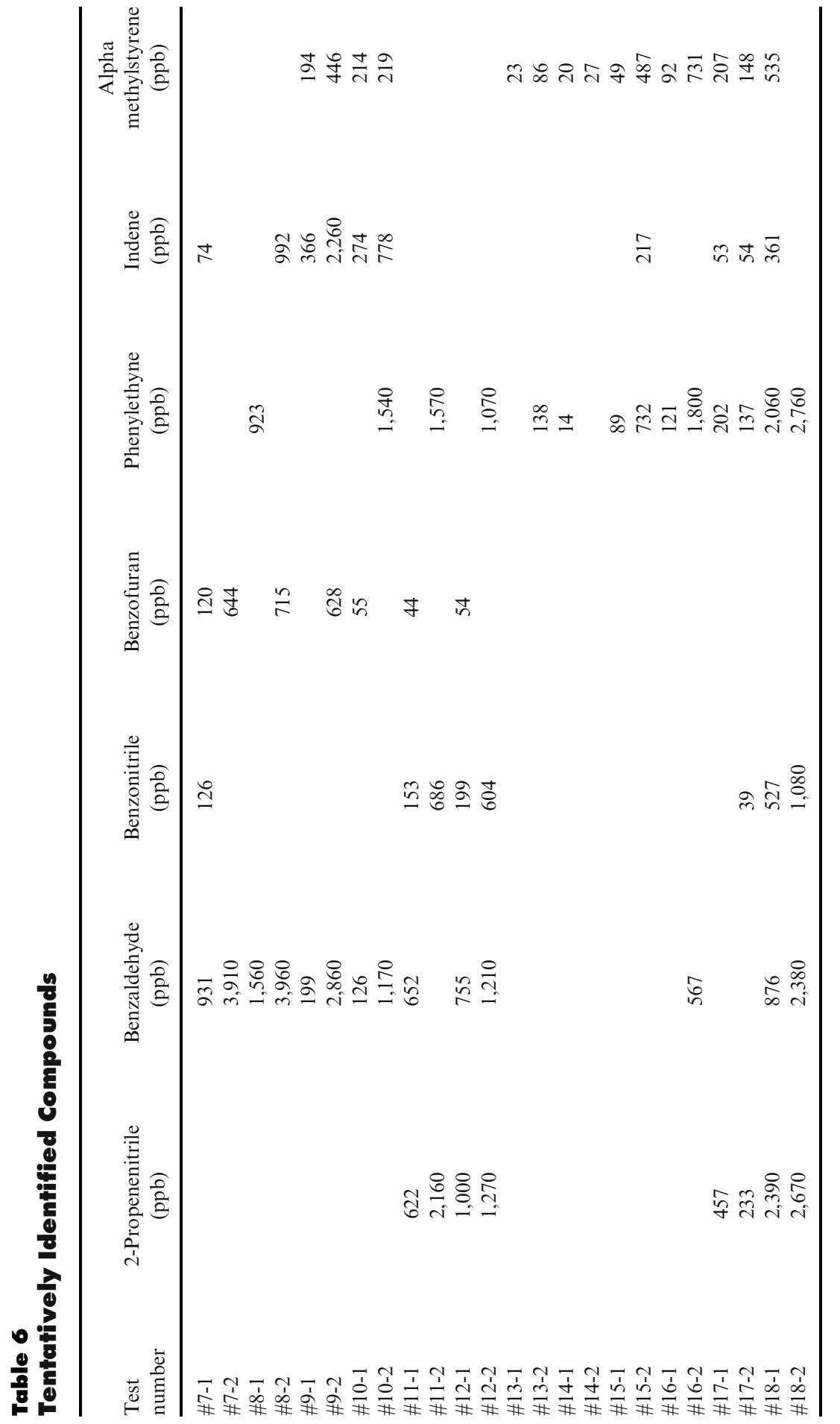


components of the televisions. Many of the monomers like styrene and butadiene are present in fairly high concentration in the smoke. The faster the plastics burned the more products of incomplete combustion were produced. Bromomethane was produced in roughly the same amounts whether or not the case contained brominated FRs. The Brazilian and Mexican market televisions produced significantly greater concentrations of acrolein in most cases.

\section{Conclusions}

For the televisions tested in this study, US market televisions contain significantly greater amounts of bromine and antimony in the plastics comprising the cases than corresponding televisions purchased in Mexico or Brazil indicating the US televisions were designed to be resistant to external ignition. This design characteristic was confirmed as US market televisions also showed much greater resistance to ignition of the casing to an external open flame. It required more than ten times the energy with extended exposure to cause these televisions to ignite and in four out of the six trials the televisions did not achieve sustained ignition. In the two cases where sustained ignition for the US market televisions occurred, it was not the FPD television itself which ignited, but the stand and mounting bracket leading to fire growth. The stands ignited early and provided a larger ignition source for an extended period resulting in the larger fire. These televisions had cases that were resistant to a candle sized flame ignition. Even with the ignition of these televisions the fire growth was slower and had lower pHRR than the Mexican and Brazilian market televisions. The television of the 2US design did not pass the UL-94 test but did contain $9.7 \%$ tris(tribromophenoxy) triazine and $1.67 \%$ antimony which delayed combustion compared to the $2 \mathrm{~B}$ models. The $2 \mathrm{~B}$ model did not contain detectable levels of antimony or bromine.

Under more severe ignition conditions the television cases protected with FRs can be ignited but tended to burn more slowly with lower pHRR release than unprotected (non-FR) cases. Not surprising, once forced to ignite, the brominated FR containing cases produced significantly greater amounts of BDD and BDF than did the corresponding non-FR FPD televisions. The levels detected for these chemicals is of the same magnitude as those detected by Blomqvist et al. [22]. This same reference compares the toxicity of the larger production of poly aromatic hydrocarbons produced in fast burning, non-flame retardant styrenic plastics, to the halo-dioxin and furans production. The trade off of BDD and BDF for PAH does not result in a decrease in overall toxicity. All of the FPD televisions which burned generated smoke and combustion products which are always toxic. This reinforces the fact that it is important to minimize the amount of combustion products generated by improving fire performance. This is particularly relevant to the practice of open pit burning of waste E\&E, where extensive emissions of smoke and combustion products result. It is, therefore recommended that open pit burning of waste E\&E products be prohibited.

Combustion gases for the faster burning televisions contain more carbon monoxide, acrolein, and benzene than the slower burning US market televisions. The 
greater the mass of FPD television consumed in fire the higher the production of these toxic chemicals. Also detected were the monomers and their degradents of the plastics used in the manufacture of the FPD televisions. As seen in test\# 13 and 14 where ignition was suppressed, only small amounts of toxic chemicals were produced to include BDD and BDF, see Tables 3, 4, 5 and 6.

One very important and unexpected finding was uncovered during this study. The stands sold with US Market televisions in this study were not resistant to a needle flame ignition source and had not been listed as meeting UL-94 V0. This applies to all components of the stand including the mounting bracket for the television which is in direct contact with the television case. As noted in the results section, once the stand was ignited the fire was sufficiently intense and of long enough duration to cause US Market televisions to ignite and be consumed. It is recommended that the ignition resistance requirement in applicable standards for the case be extended to the accessories attached to the television especially wall mounting brackets and table stands.

The $5 \mathrm{~min}$ to $10 \mathrm{~min}$ of HRR above $100 \mathrm{~kW}$ is more than sufficient to ignite nearby combustible materials from direct flame impingement (piloted ignition) and radiant pyrolysis and could lead to rapid fire growth in a structure fire. This was noted in all of the non-FR FPD televisions tested while only two of the nine FR televisions tested in this program achieved this level of HRR. The two FR FPD televisions that produced HRR at this level involved the non-FR stands. In addition, burning droplets were noted in several cases where pool fires resulted under the televisions and this could also lead to rapid fire growth where other combustible materials are present in the cabinets, tables, stands or carpets where the televisions may be located.

The televisions tested in this program were all in the 32 inch to 40 inch range. These are relatively small for today's market where 50 inch and 60 inch models are relatively common. The increased mass of plastics in the larger cases and the larger surface areas would result in larger total heat content as well as increased pHRR. Therefore, the values presented here are on the low end for expected values found in modern homes.

\section{Acknowledgments}

This work was funded by the North American Fire Retardant Association and the American Chemistry Council.

\section{Open Access}

This article is distributed under the terms of the Creative Commons Attribution License which permits any use, distribution, and reproduction in any medium, provided the original author(s) and the source are credited. 


\section{References}

1. Troitzsch J (1998) Fire safety of TV-sets and PC-monitors, prepared for: European Brominated Flame Retardants Industry Panel, European Flame Retardants Association. http:// www.ebfrip.org/uploads/Press/documents/Troitzschfinalreport.pdf. Accessed 25 Sept 2014

2. Troitzsch J (1999) Flammability and fire behaviour of TV sets. http://www.iafss.org/ publications/fss/6/979/view. Accessed 25 Sept 2014

3. De Poortere M, Schonbach C, Simonson M (2000) The fire safety of TV set enclosure materials. A survey of European Statistics. Fire Mater 24:53-60

4. Blomqvist P, Rosell L, Simonson M (2004) Emissions from fire part 1: fire retarded and non-fire retarded TV-sets. Fire Technol 40:39-50

5. Hall John R (2002) Fires involving appliance housings - is there a clear and present danger?. Fire Technol 38:179-198

6. Hoffmann JM, Hoffmann DJ, Kroll EC, Kroll MJ (2003) Full scale burn tests of television sets and electronic appliances. Fire Technol 39:207-224

7. UL (2014) Video on YouTube. http://www.youtube.com/watch?v=aDNPhq5ggoE. Accessed 13 June 2014

8. Kerber Stephen (2012) Analysis of changing residential fire dynamics and its implications on firefighter operational timeframes. Fire Technol 48:865-891

9. Gardner R, Browner R (1980) Determination of polymer pyrolysis products by gas chromatography and gas chromatography/mass spectrometry. Anal Chem 52(8):1360-1364

10. Wilkie C, Morgan A (2010) Fire retardancy of polymeric materials, 2nd edn. CRC Press, New York

11. Weil E, Levchik S (2009) Flame retardants for plastics and textiles. Practical applications. Hanser, Cincinnati

12. Horrocks A, Price D (2008) Advances in fire retardant materials. CRC Press, New York

13. Blum A (2012) The Case Against Candle Resistant TVs, version 3-28-2012. http://www. greensciencepolicy.org/wp-content/uploads/2013/11/Current-Case-against-CandleResistant-TVs-IEC-March-28-2012.pdf. Accessed 25 Sept 2014

14. Cooper K (2012) L-IEC 108 - Canadian Environmental Law Association. http://s.cela. ca/files/L-SCC-IEC-108-candle-resistant-TVs_0.pdf. Accessed 3 Jan 2014

15. Merson G (2011) HDTVs are catching fire... literally. http://www.nbcnews. com/technology/hdtvs-are-catching-fire-literally-123020. Accessed 13 June 2014

16. CPSC (2014) Thirteen Retailers Recall 32" Coby Flat Screen Televisions Due to Fire and Burn Hazards. http://www.cpsc.gov/en/Recalls/2014/Thirteen-Retailers-Recall-32Coby-Flat-Screen-Televisions/. Accessed 13 June 2014

17. Baker B (2013) Flat screen TV recall: 32-inch big screen TVs recalled over fire hazard. http://www.examiner.com/article/flat-screen-tv-recall-32-inch-big-screen-tvs-recalledover-fire-hazard. Accessed 13 June 2014

18. Peckham M (2011) 1.6 Million Sony Bravia TVs Might Catch Fire, Free Inspection Offered. http://techland.time.com/2011/10/12/1-6-million-sony-bravia-tvs-might-catchfire-free-inspection-offered/\#ixzz2rpGRoIUK. Accessed 3 Jan 2014

19. Durso F (2013) TV Catches Fire While Family Sleeps. http://nfpatoday.blog.nfpa.org/ 2013/10/tv-catches-fire-while-family-sleeps.html. Accessed 12 Dec 2013

20. Clarke F, Ottoson J (1976) Fire death scenarios and fire safety. Fire J 70(3):20-22

21. Weil E, Levchik S (2009) Flame retardants for plastics and textiles, practical applications. Hanser, Cincinnati

22. Blomqvist P, Rosell L, Simonson M (2004) Emissions from fire part 1: fire retarded and non-fire retarded TV-sets. Fire Technol 40:39-50 